\title{
The Influence of Authority, Initiative, and Unity of Direction in Achieving Good Governance in Africa using Mplus v8 Scientific Tool
}

\author{
Abdul-Kahar Adam ${ }^{1,2, *} \quad$ Nasser Salim Mohammed Alsadi ${ }^{1} \quad$ Ebi Shahrin Suleiman ${ }^{1}$ \\ 1.Universiti Teknologi Malaysia (UTM), Azman Hashim International Business School, Skudai, 81310 Johor \\ Bahru, Malaysia \\ 2.University of Education, Winneba, Business School, P.O. Box 25, Winneba, Central Region, Ghana \\ *Email: aka11@live.co.ukakadam@uew.edu.gh aabdulkahar2@graduate.utm.my \\ ORCID: https://orcid.org/0000-0001-8469-465X \\ ORCID: https://orcid.org/0000-0002-6423-1751 \\ ORCID: https://orcid.org/0000-0003-4908-5888
}

\begin{abstract}
This is an inductive and applied research study with the application of both quantitative and qualitative methods using Mplus v8 and presented the findings. The study targeted how authority, unity of direction and initiative are used in the public sector organisations in Ghana through organisational charts and structures. The research primary source of data is Ghana National Association of Teachers (GNAT) and of which 55 sample size were collected within GNAT in Tamale, Northern Region. GPower 3.0.10 was also used to calculate this sample size to support the data analysis. The research findings shows that the public sectors in Ghana organisational charts needs to be transformed or changed completely to suite the public sector as humble institutions and not a bossy type of organisation's jobs. The occupants of the public sector organisations are supposed to serve and not as directors. The model of the hypothesis shows that there is positive relationship between authority and good governance, also, it indicated a lower coefficient for initiative which correlates with good governance, whereas, the analysis shows that there is negative relationship between unity of direction and good governance. By this it means that there is the need for more concentration on unity of direction. As former President Obama once said that Africa does not need strong men but rather Africa needs strong institutions (New York Times report, 2009), and this is the only way Ghana and Africa can build its human capital towards achieving good governance by adopting the findings in this research.
\end{abstract}

Keywords: authority, unity of direction, initiative, public sector, good governance, organisation, charts, structures, Ghana

DOI: $10.7176 /$ PPAR/9-4-05

Publication date: April $30^{\text {th }} 2019$

\section{Introduction/Background}

This research is basically looking at the ways and means through which good governance can be achieved either by the influence of authority, initiative, and unity of direction. By this it means that for Ghana to be able to achieve some aspect of good governance then there is the need to check the internal consistency and relationship of the workforce applying authority, initiative, and unity of direction within the public sector of the economy. Day-in-day-out in Ghana and elsewhere in Africa it is commonly reported that governments always fail to deliver to the expectation of its citizens and society. This is because there are rampant issues of unemployment, financial malfeasance, poor attendance to work, lack of time management, lack of proactive of the employees in the public sector offices, bribery and corruption cases, and inconsistency of systems, structures of policy implementation and delivery. With all these issues as stake, it will be impossible for a country to prosper in order to achieve good governance. In other words, if the social conditions of the citizenry are not improved to an appreciable level to reduce hardships then there are problems in the way human resources are applied at the expense of lack of authority, lack of initiative, and lack of unity of direction. In this research, an organisational chart and structure of the public sector is the reference point as to how these independent variables (authority, initiative, and unity of direction) influences good governance as the outcome.

These variables such as authority, initiative, and unity of direction are some of the 14 principles of management identified by a classical theorist, Henry Fayol. Fayol was a factory worker who rose to the top management position at a time when the factory productivity was dwindling; he therefore initiated 14 principles and worked with them by instituting clear guidance in accordance, which he succeeded to improve the factory business by increasing the prospects and growth of the business. Therefore, this theory was adopted by many companies in the $21^{\text {st }}$ centuries and it really worked for them and their companies. Hence, it is prudent to study and relate some of these established principles of management defined by Henry Fayol and apply it to governance sectors within the public administration and see if there can be positive significance to the 
relationship of authority, initiative, and unity of direction as independent variables that cause and influence good governance. This means applying and incorporating some of the corporate or private sector management principles identified by Henry Fayol into the Public Sectors/Government establishments for correlations.

The main purpose of this research paper is to examine these independent variables (authority, initiative, and unity of direction) in the governance of public sector context for its viabilities towards attaining good governance. Government and Governance are interchangeably used in most dictionaries, where it shows authority in an organization, institution or a state. Government is referred to a name given to the entity, body or a person to exercise that authority and this authority is simply defined as a legitimate use of power and having the right to do so, whereas power is also, simply the ability to influence the behaviour of others. Therefore, authority is based on an acknowledged duty to obey rather than on any form of intimidation or manipulation or coercion. Heywood, (1997) stated, to study government is to study the exercise and practice of authority. It further noted that the study of politics is restricted to state actors who are consciously motivated by their ideological beliefs, and seeks to advance these beliefs through membership of a formal organization they establish, which is a political organization. This is why politicians are described as political and civil servants (who are noted as non political), and the state is seen as public and the civil society are referred to as private and corporate.

Governance is the sound exercise of political, economic, and administrative authority to manage a country's resources for development, involves the institutionalization of a system through which citizens, institutions, organizations, and groups in a society expresses their interests, exercise their rights, and mediate their differences in pursuit of the collective good of a nation (Asian Development Bank, 2005). The United Nations Development Programme- UNDP, (1997) also defined good governance in their policy document programmes with the title "Governance for Sustainable Human Development" as the exercise of economic, political and administrative authority to manage a country's affairs at all levels. It is stated that there is a distinction between decentralising units of operation and decentralising authority which countries must take care of accordingly if they want to achieve good governance through their organisational structures/charts in best practice.

1.1 Research Question, Objective, and Hypothesis

\begin{tabular}{|l|l|l|}
\hline $\boldsymbol{R} \boldsymbol{Q}$ & $\boldsymbol{R O}$ & Hypothesis \\
\hline $\begin{array}{l}\text { Is there any relationship between } \\
\text { authority and good governance? }\end{array}$ & $\begin{array}{l}\text { To examine the relationship } \\
\text { between authority and good } \\
\text { governance. }\end{array}$ & $\begin{array}{l}\text { H1: Authority is positively } \\
\text { significant to good governance. }\end{array}$ \\
\hline $\begin{array}{l}\text { Does unity of direction have direct } \\
\text { influence to good governance? }\end{array}$ & $\begin{array}{l}\text { To examine the way unity of } \\
\text { direction influences good } \\
\text { governance. }\end{array}$ & $\begin{array}{l}\text { H2: Unity of Direction is positively } \\
\text { significant to good governance. }\end{array}$ \\
\hline $\begin{array}{l}\text { Is there any correlation between } \\
\text { initiative and good governance? }\end{array}$ & $\begin{array}{l}\text { To identify the correlation between } \\
\text { initiative and good governance. }\end{array}$ & $\begin{array}{l}\text { H3: Initiative significantly } \\
\text { correlate to good governance. }\end{array}$ \\
\hline
\end{tabular}

\subsection{Problem Statement}

The bases of this research are whether some of the principles of management in Organisational Behaviour through organisational charts and structures within the corporate sectors are the same practice in the public sector that is expected to drive good governance as the outcome? In this case, a lot of organisational challenges and problems are revealed according to existing structures in the public sector organisations. The issues are how does public sector organisations implement the following in their organisations are what needs to be addressed by finding out through this investigation.

No organisational method or design of management is deemed perfect (Davis and Lawrence, 1978) and that it can have any form of problem due to the design itself. Davis and Lawrence, (1978), actually researched on a new form of organisation chart or structure known as the Matrix, that is, companies or organisations turn to matrix form when their biggest responsibility belongs to two sectors of the organisation simultaneously. For example, in the public sector are the ministries, departments, agencies, and enterprises of the state. Matrix also occurs, when there is very high requirement of information production due to uncertainties and also when there is a major constraint in government to deal with human resources problem such as unemployment, and financial matters. But the following are the ills or problems with Matrix that is power struggles, tendencies towards anarchy, excessive overheads, severe groupitis, sinking to lower levels, plans collapse during economic crunch, decision strangulation, navel gazing, and uncontrolled layering. This is basically the point of this research to see how these problems affect good governance outcomes from the public sectors operations and service delivery (Davis and Lawrence, 1978). Below is the main approach to organisation, structure and its management: 


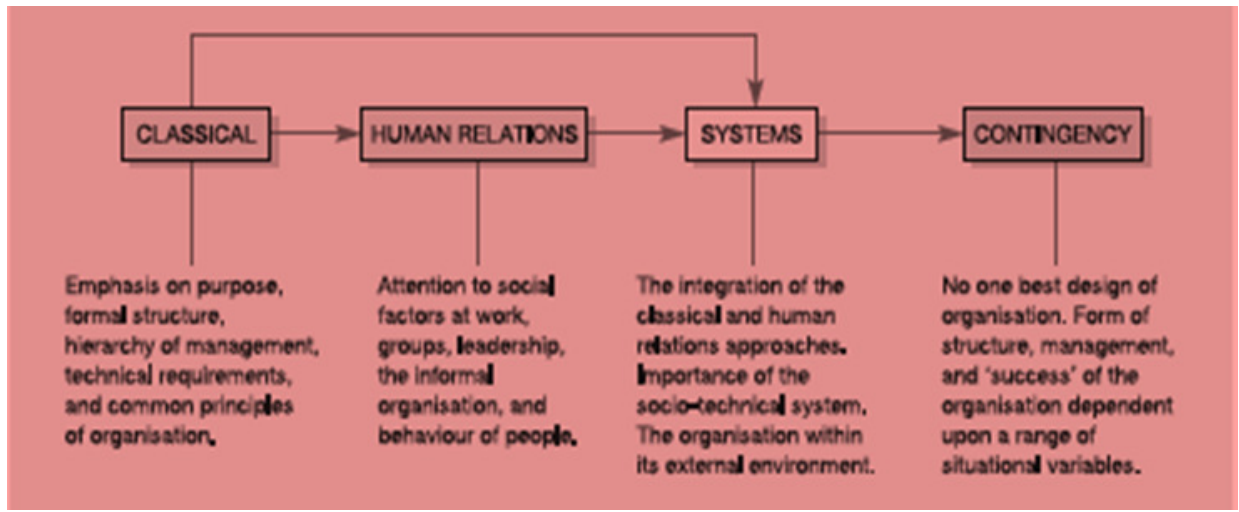

Figure 1.Main Approaches to Management Structures, and Organisational Behaviour

Source: Skipton, (1983), 'Management and the Organisation', Management Research News, vol. 5, no. 3.

According to Christensen, et al., (2007), stated that public organisations are not new phenomena to reforms and changes, and that the issue mainly has to do with how the central authority for public services like ministries and any autonomous public agency has been a centrality of controversy in many countries such as Australia or Sweden, and Ghana is not an exception to this problem. Even how to pass delegation through the structures of government institutions are not easy in practice and the comprehensive launch of reform programmes is something new and therefore it is not easy to understand and practice its functions across board. The organisations hierarchical base instrument for change perspective or running an organisation is in the hands of the leadership and superior people in authority (Christensen, et al., 2007). The figure 1 above shows how the processes of management principles are set in an organisation through the process of putting emphasis on structures and purpose, human relations as attention to social factors, systems of integration, and contingency planning since no one design of an organisation is the best. The below figure 2 is an organisational chart for the Public Services Commission (PSC) that shows how authority, initiative and unity of direction flow.

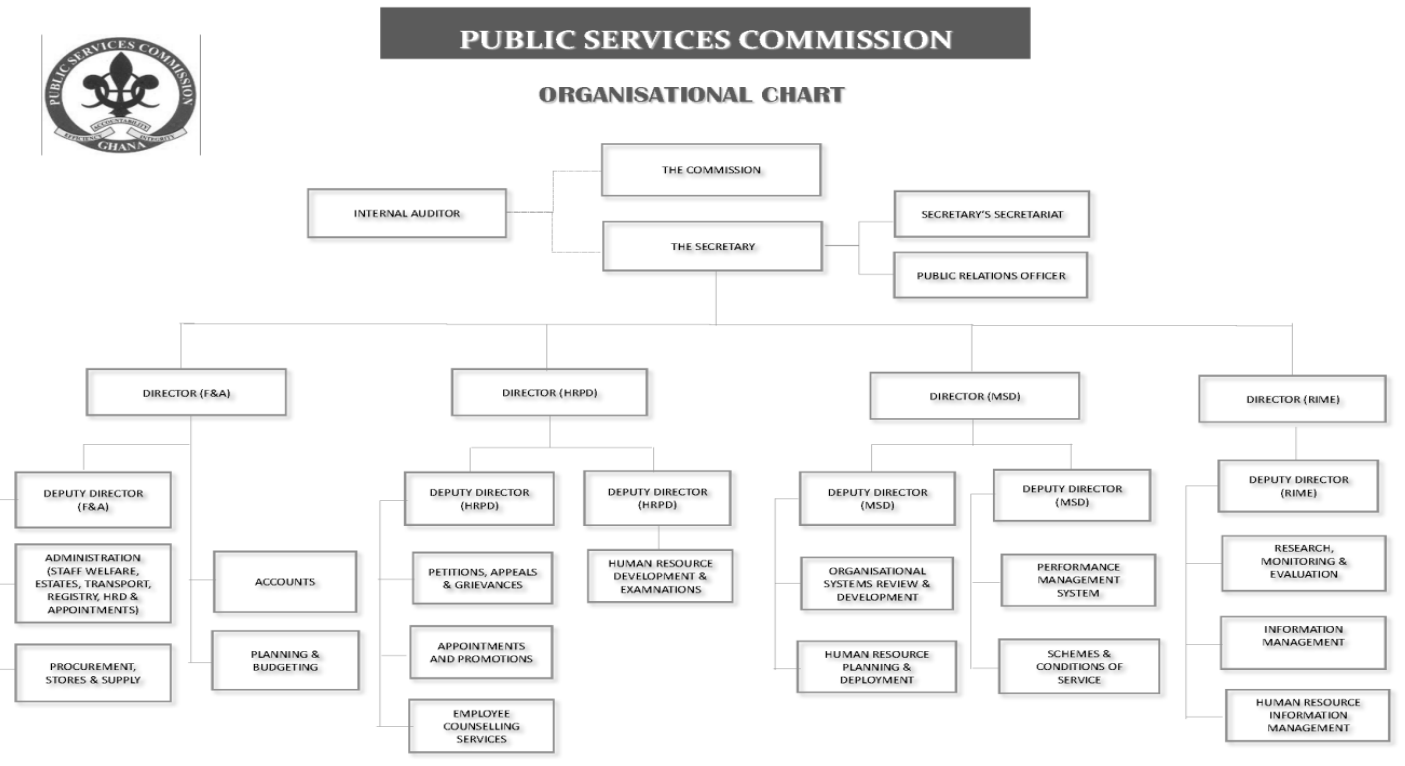

Figure 2. Organisational Chart of Public Services Commisson - Ghana.

Source: Public Services Commission official website

Following the above figure 2 raises the question as to how the leadership and superiors use their authority over the public sector workers. First of all in the organisational structure there cannot be 'The Chairman' as the top executive. This clearly shows how structures are not properly designed to effect good governance. Is a Chairman part of a-day-to-day routine staff? That is a contradiction to investigate. Hence, the PSC Organisational structure is not professionally designed as per best practice. Are the employees allowed to use their initiatives as to when there is the need? Is there clear unity of direction as some termed it as unity of objectives? The fact of the matter is that this organisation chart exist and working but still there are many issues and problems with the systems in Ghana which need to be investigated to ascertain whether these principles with the chart are been well designed in best practice? The issue with the above organisational chart is whether 
after this there is a Board of Directors structure in existence and if so, will they be another Board Chairman?

According to Akrani, (2010), stated that the general understanding of organisation and management is the start of the process and the outcome which is the end results of the processed product designed and this can be achieved through what is termed Organisational Chart or Structure. This serves as the foundations of the overall operation of the management organisation which is an essential part in conducting all the business activities of the organisation in an efficient and effective manner. The idea here is that how it is practiced in the public sector organisation by the authorities with such responsibilities if the design and implementation of the management principles are wrongly applied? In this case the soundness of the organisation structure would be determined through the success of the management processes used or adapted at work. This will be assessed in line with the authority, initiative, and unity of direction to ascertain if this is how interpersonal relations help to achieve good governance in the public sector?

Below figure 3 is other different type of organisational charts/structures through which the variables authority, initiative, and unity of direction exist and whether the outcome supports the success of good governance or not is what this research paper is set to achieve. Again, the question here is whether the Board of Directors placed at the top is proper way to exercise authority in an organisation?

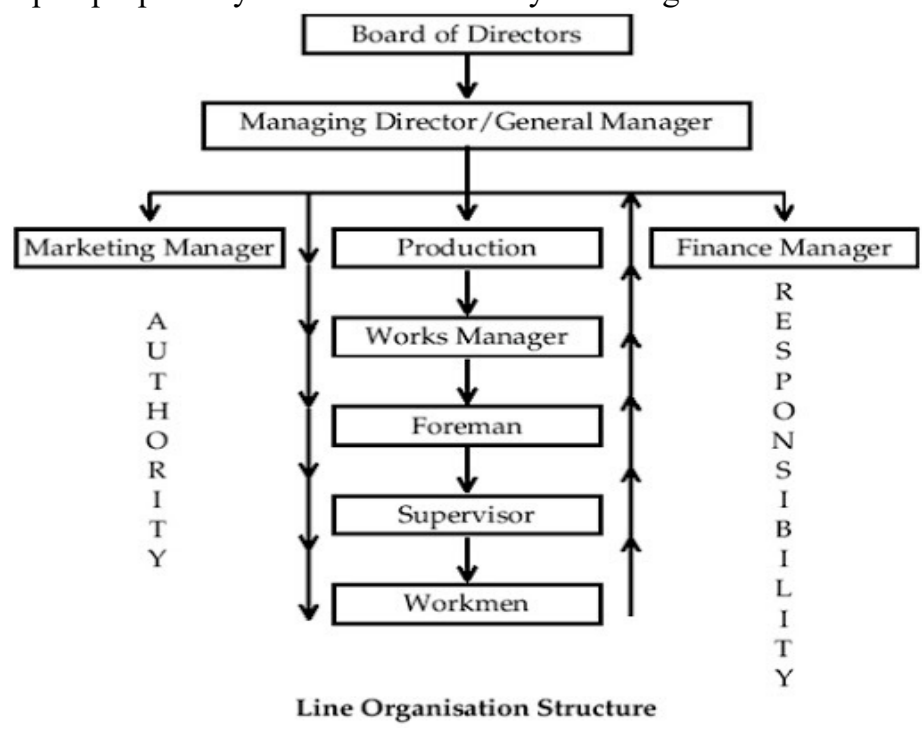

Figure 3.Line Organisation Structure

Source: Akrani, (2010), Organisation - Organisation Structure - Organisational Chart

The above figure 3 shows the top-down approach which is termed Authority and the bottom-up approach which is also termed responsibility given and also performed by the lower managers and staff. The fact of the matter is does this really apply or work effectively and efficiently in the public sector organisations through the authority, initiative, and unity of direction? There is a question that contradicts the work of a Manager, Foreman, and Supervisor? It is contradictory when it comes to the application of general authority, initiative, and unity of direction. Below is also an example of line and staff organisation chart through which the principles of management functions exist. 


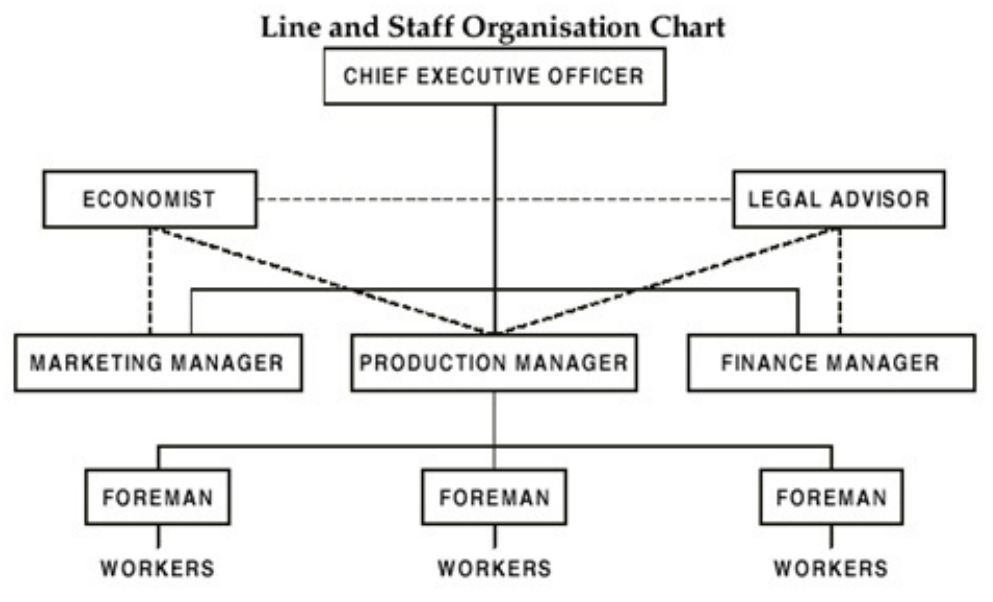

Note: Straight lines represent line and broken lines represent staff.

Figure 4. Line and Staff Organisation Chart

Source: Akrani, (2010), Organisation - Organisation Structure - Organisational Chart

The above figure 4 shows the information and responsibilities that follows in an organisation where the line mangers exercise their authority to their staff (subordinates) and as to whether they are allowed to use their initiatives and also follow a unity of direction (objectives) within the public organisations (where there are elected governments and political workers). Above all, how does the public organisational structure effects good governance that the governments and politicians are geared to achieve under the constitution as democratic practice? This is what this research paper is attempting to achieve. According to Akrani, (2010), argued that the following presents the reasons why conflicts may occur between the line executives and staff members. The critical issue also is that in this chart there is a contradiction between positions of Economist and Legal Advisor over the Marketing, Production, and Finance Managers. How will they exercise authority, initiative, and unity of direction?

\begin{tabular}{|c|c|c|c|}
\hline \multicolumn{4}{|c|}{$\underline{\text { Reasons/Causes for Conflict }}$} \\
\hline & $\mathbf{A}$ & & B \\
\hline & $\Gamma$ & & - I \\
\hline \multicolumn{2}{|c|}{$\begin{array}{l}\text { Arguments of Line Executives } \\
\text { against Staff }\end{array}$} & \multicolumn{2}{|r|}{$\begin{array}{l}\text { Arguments of Staff Executives } \\
\text { against Line }\end{array}$} \\
\hline (1) & Dilution of Authority. & (1) & Resistance to new plans and ideas. \\
\hline (2) & Stealing show. & (2) & Inadequate support from line executives. \\
\hline (3) & Lacks practical knowledge. & (3) & Inadequate scope for the use of authority. \\
\hline (4) & Lacks human skills. & (4) & Lack of support from top management. \\
\hline (5) & Domination of staff managers. & (5) & Limited cooperation from line executives. \\
\hline (6) & Easy access to top management. & (6) & Supply of inadequate information. \\
\hline (7) & Stress on paperwork. & (7) & Absence of authority. \\
\hline
\end{tabular}

Figure 5.Line and Staff conflict

Source: Akrani, (2010), Organisation - Organisation Structure - Organisational Chart

The above figure 5 depicts the reasons and causes of conflict among line and staff within organisation. There is dilution of authority under the staff whereas there is resistance to new ideas and plans. Also, there is too much stress on paper work on the staff whereas there may be absence of such authority of responsibility. Hence, the need to investigate to see if this is how the public sector organisation of government appointees and staff behaves. This line and staff organisation structure includes the civil service personnel as an integrated component under the Public Service Commission (PSC). Below is a complete organisation chart and structure which is defined as a pictorial view of the flow of responsibilities of positions and information or communication within an organisation. It also shows the functions, relationships, channels of supervision and clearly defines authority levels. Organisation chart is when there are no real human resources employed into the specified positions (that is from planning to setup stage), and the chart is always organisational initial picture of positions. The below chart seems to be a good practice or best design where the CEO is the top management or executive and above is board of directors separated from the chart. This is an excellent organisational chart that can achieve organisational goals and objectives. 


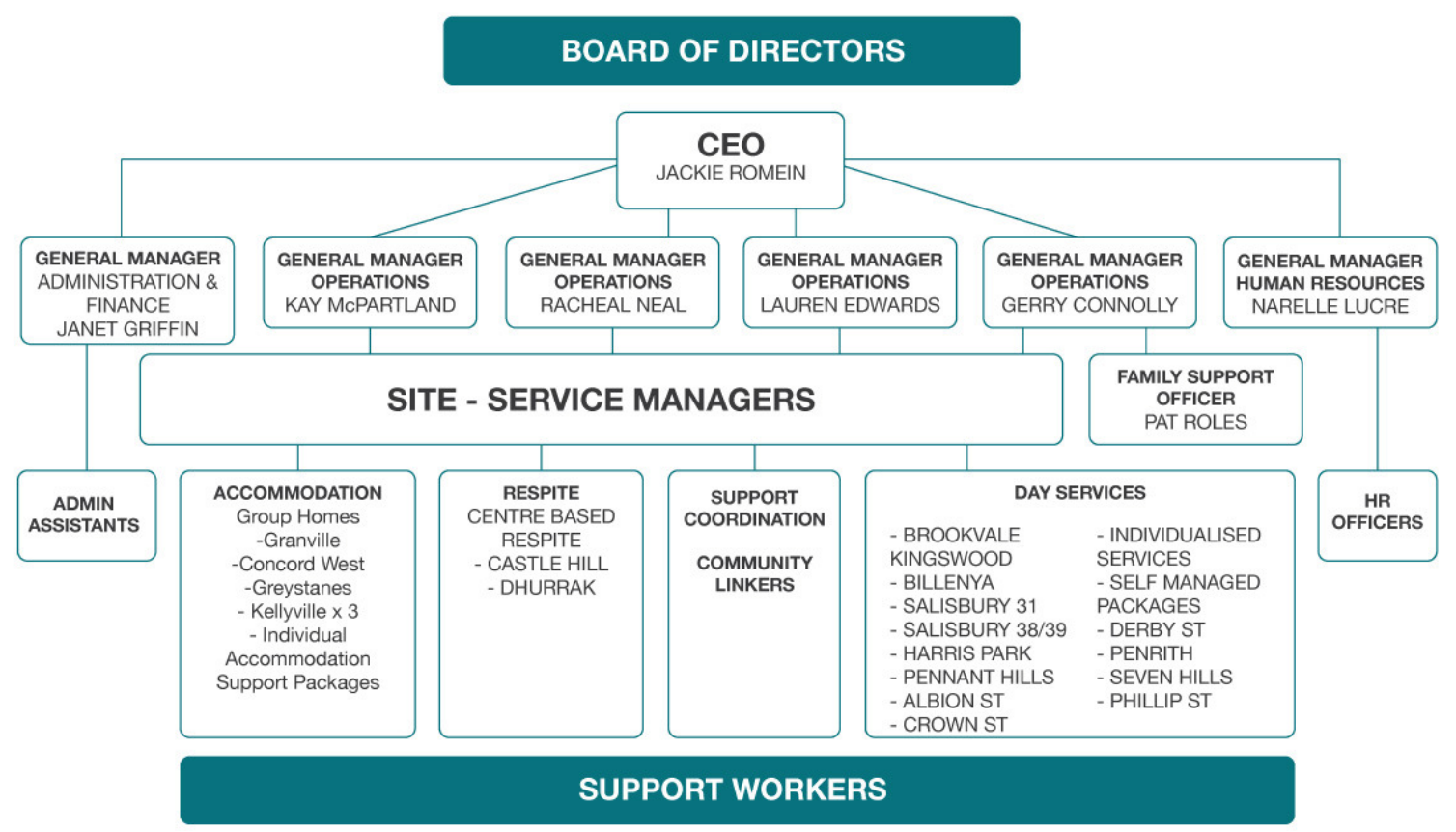

Figure 6. Flinctwood Organisational Chart

Source: https://www.flintwood.org.au/organisational-chart/ (accessed 01/01/2019)

Below is an organisational chart for Local Government of Ghana.

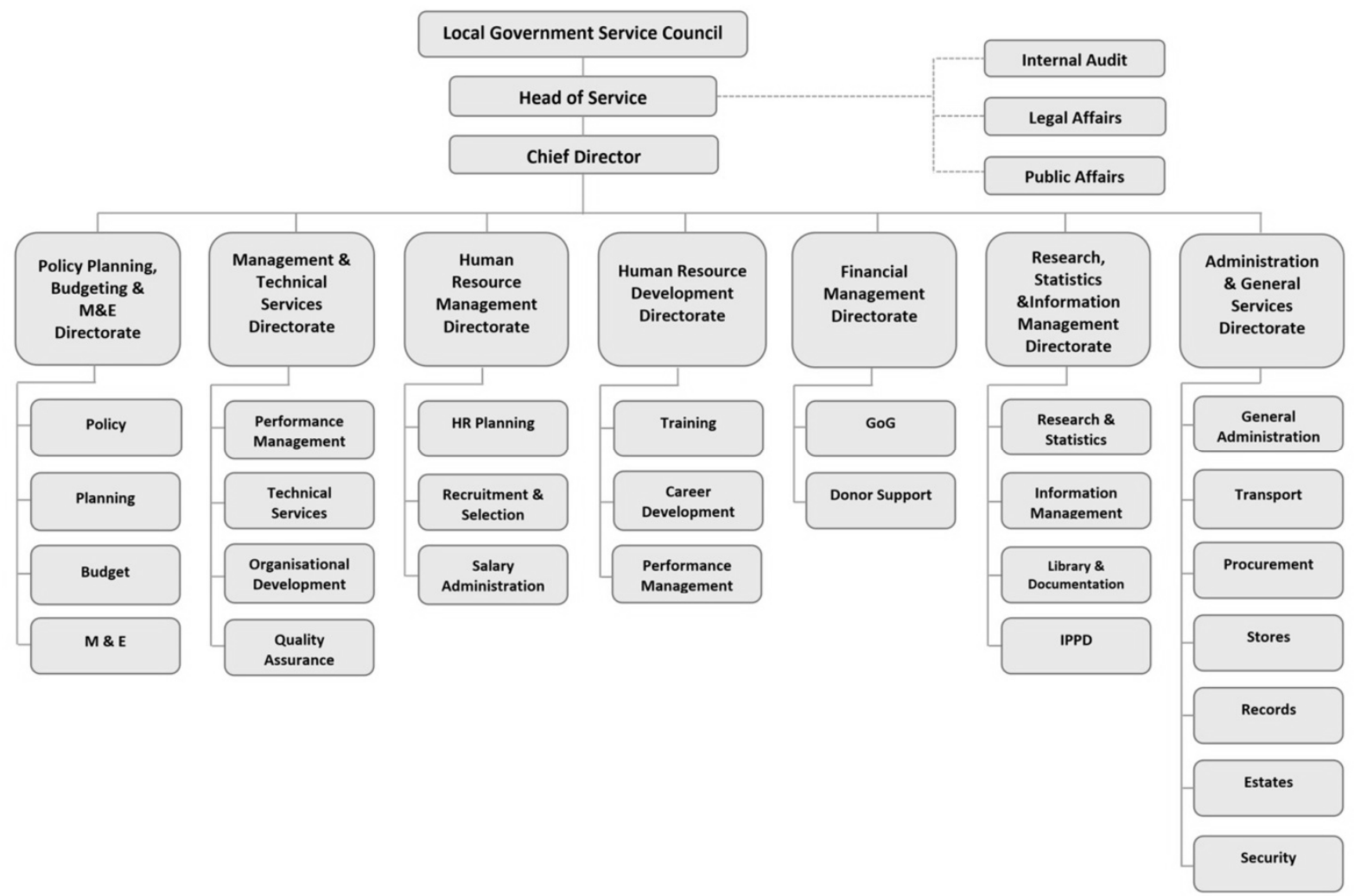

Figure 7.Local Government of Ghana Organisational Chart

The above charts shows how the public servants or officers and civil servants operates towards making attempts to achieve socio-economic growth of the people to be translated into good governance as the outcome. This is the myth that this research paper want to clarify as to whether both public officers (government appointees) and civil servants are actually practicing effective authority, using initiatives by staff or workers, and if there is unity of direction or objective at all they have been fulfilling? Again, the Local Government 
Council is placed at the top in this structure which serves as the Board of Directors role in corporate sense. This is not a best practice if a country wants to achieve good governance through authority, initiative, and unity of direction. Also, the Internal Audit, Legal Affairs, and Public Affairs have no links what so ever to the rest of the line management which is a bizarre structure. How can authority, initiative, and unity of direction flow? This speaks how Ghana's decision making bodies in the public sectors has loopholes that needs fixing or correcting for good governance to be achieve as best practice.

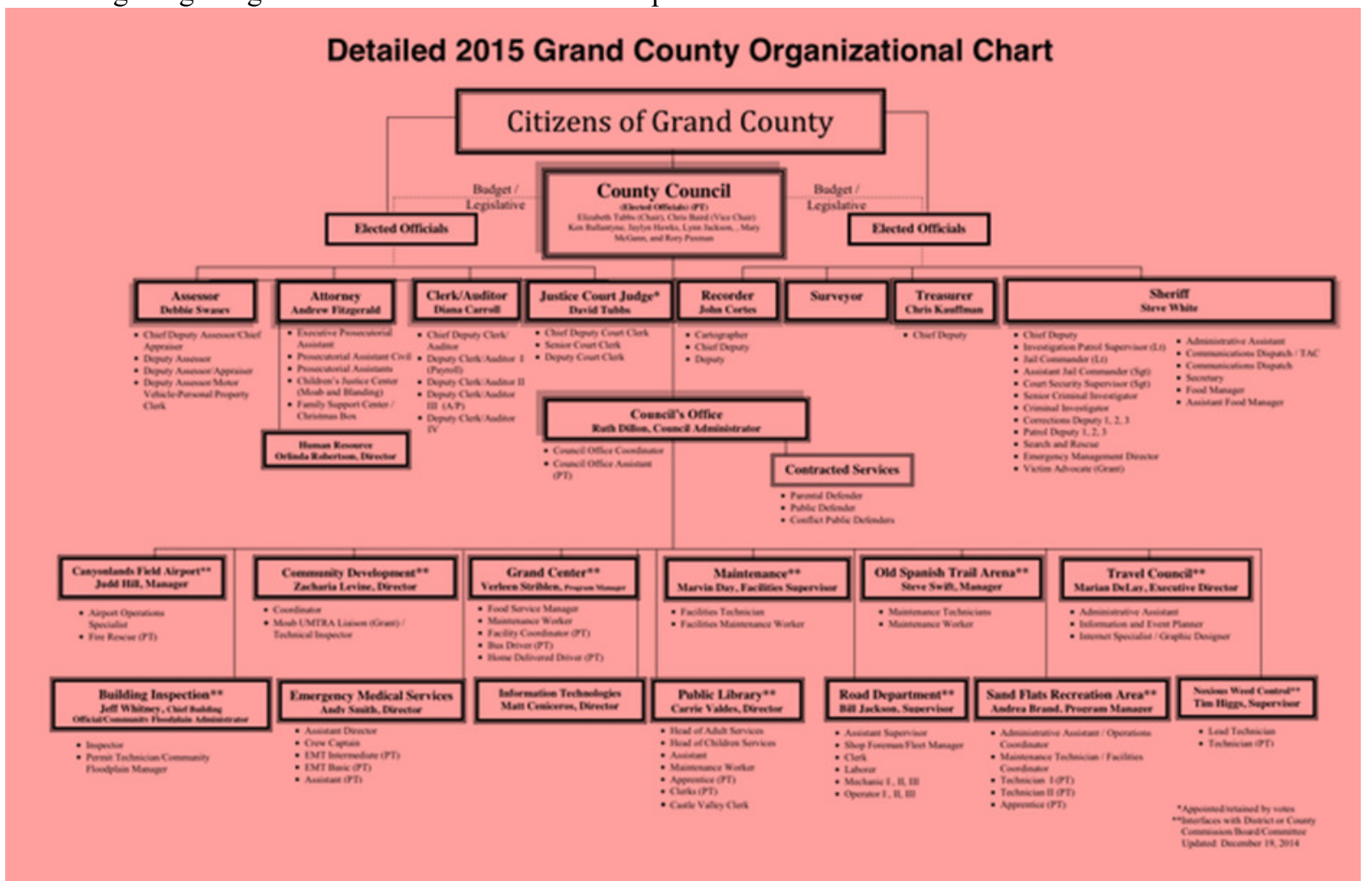

Figure 8.Grand County Organisational Chart

In figure 8 above, it shows clearly how advanced nations regard their citizens in the use of authority, initiative, and unity of direction at the highest level. This is what public sector organisation in terms of practicing the principles of management by African countries to adopt this design by putting the people first. The above chart has its Citizens as the top managers or executives of the county, which means the citizens authority, initiative, and unity of direction is paramount about the county executive officers. This is best practice probably that is why they are always ahead of African countries and Ghana is an example. There is contradiction in authority towards achieving outcomes and being parish or sanctioned by a Minister is wrong is committed (Aucoin and Heintzman 2000; Aucoin, 2012).

\section{Literature Review}

This is to provide the theories and secondary sources that best explains authority, initiative, and unity of direction in line with the objectives of this research paper.

\subsection{Authority}

Power and authority in any organization should be decentralized without undermining corporate cohesion. This will encourage the creation of new ideas and the harnessing of staff creativity. Centralize organisations use of power and authority. Moreover, this paradox is resolved by the theory that managers need greater management authority for management to secure desired outcomes that follow from more explicit policy and program direction from ministers, who in turn hold them to account for not meeting the public expectations if that is the outcome (Aucoin and Heintzman 2000; Aucoin, 2012). From this theory, it is important to look for answers to questions like; has the government always set up strategies and implement some of the Henry Fayols 14 principles of Management in the Public Administration? Are the people working in the public sector efficient, and what are the remedies if they do not achieve good governance in practice? The problems that this research tries to solve is how satisfied are the people with their government policies and programmes on the basis of good governance that the organisational charts and structures are to fulfil by this objective (Aucoin, 2012). Authority by leaders and top managers are essential to the effective operation of administrative systems and implementation of administrative procedures in order to achieve good governance (Feldman and Khademian, 


\section{1).}

In complex government structures what counts after political will fades due to lack of trust is that, the organizations and institutions can only be viable if there is sound authority and part of this viability is effective on independent leadership within the organizations. If no one is responsible for continuity during transitions of political authority, it is very difficult for organizations to maintain their effectiveness likewise in Ghana for instance. Some governments form commissions while others appoint independent officers in their respective administration to undertake certain investigative issues not even to work on economic policy delivery. Ethics and codes become more effective over time in governance where authority, initiative, and unity of direction are common examples. The longer these ethics and codes are in placed the more natural they seem to the public service environment for good outcomes. They also become integrated into the overall management structure and are seen by the public as an effective tool in delivering good governance. However, codes also create friction for example, if there is no political will and institutional importance to nurture its organic development, the code will have less and less impact in achieving good governance just as the cases in Ghana government structures (Gilman, 2005).

Leadership and top management without authority affects the smooth operation of administrative systems and policies (Feldman and Khademian, 2001). People in authority are part of a problem of a state because of their posture and difficult bureaucratic nature makes it difficult to achieve developmental needs to gain good governance status (Haruna and Kannae, (2013). Lack of independent authority within organisation can fade away due to no political will (Gilman, 2005). It also challenged the de facto independence of the public service from government and further seeks to assert ministerial direction and control as appropriate to ministers as government and executive heads of departments in the Westminster model. Ironically, empowering managers on one hand and then also putting political control over the mangers on the other hand, makes the New Public Management (NPM) reforms contradictory (Aucoin, 1990; Aucoin, 2012). And by this paradox it can be referred to the theory that says managers need greater management authority for management in other to secure desired outcomes from more explicit policies and programs direction from ministers, who in turn hold them to accountable if expectations are not met (Aucoin and Heintzman 2000). Advocates argued that greater political control of policies and programs in the hands of the elected government was appropriate for democratic governance and that since this did not undermine management with partisan or political interferences in staffing or in the work of the public service that is meant to be impartial. And this was better for proper management principles in practice, since it brings focus and good results in development.

The following are the main principles of administration namely unity of command; hierarchical transmission orders, that is, chain of command; separation of powers (authority, subordination, responsibility and control); centralization; order; discipline; planning; organisation chart; meetings and reports; and accounting (Daniel, et al., 2002). Managers must have the authority to give orders and be able to delegate some duties and responsibilities, but they must also keep in mind that with authority comes with responsibility (i.e. taking charge of every situation, be it good or bad).

\subsection{Initiative}

This means staff must be encouraged to think critically and innovatively as to how to carry out their duties or tasks at hand. And also, employees should be given the necessary level of freedom to create and carry out plans. According to Godwin et al., (2017) argued that it is the duty of the managers in an organisation to provide creative ideas and skills conveniently for the staff to carry out their duties and responsibilities or any task given in the organisation effectively. As the managers initiate new ideas towards implementing them, it is important to make room for the employees to also contribute their initiatives in the growth process of the organisation towards achieving organisational objectives. By this it means that the employees can contribute their initiatives innovatively to increase production and growth. The essence of this is to see whether this principle of initiative created by Henry Fayol among the 14 principles of management really effect the work in the public sector.

The employees of an organisation have become the bed rock and idea house of organisations success in this modern era (Godwin et al., 2017). According to Magjuka, (1991; 1992) and Godwin et al., (2017) research have revealed that in the western countries where problem solving by group systems is being patronized at the expense of dependence on the top level management to be the problem solvers. Therefore, it is stated that management of every organisation should encourage employees initiatives to help implement into action. Does this work in the public organisations in Ghana? Especially, the service industry for example encourages their employees to use their initiatives to provide excellent services to clients and customers (Godwin et al., 2017) and Okpara, (2016) argued further that there are policies, processes and procedures to help support and guide the employees from abuse of the opportunity of using their initiatives. This in fact helps the implementation of systems and polices become more effective.

Ironically, Godwin et al., (2017) observed in their findings that managers of late are too busy and occupied by other several unrelated task and therefore are less initiative due to lack of concentration on specific job. This 
is a sharp contrast to the above theories submissions. Therefore, there is the need to actually carryout this investigation to see how this practice is good or it's not well practiced within public sector organisations. Godwin et al., (2017) suggested that management of organisations should increase the level of authority given to some employees to be able to initiate ideas in the absent of a senior supervisor or manager and implement same, example of organisations that created and implemented such level of authority in initiative of ideas by employees are facebook, apple, google, alibaba, amazon, etc. Though these are technological firms in service and production, they give chance to developers to bring innovations onboard. Is it the same practice in the public sector of Ghana? Since, employees are encouraged by their employees to bring innovation through initiatives the company's performance levels are so high. Therefore, Godwin et al., (2017) concluded that, Henry Fayol suggested, every good organisation must always give chance and provide the ways and means and systems for employees to tender in their suggestions with tangible ideas and thereby reward should be given accordingly to motivate employees in this direction.

\subsection{Unity of Direction}

Individuals in a team must have knowledge and understanding of the same objectives they should be working towards achieving and must also work under the direction of one manager, using a unique plan base on consensus. This will ensure that action is properly coordinated and monitored for greater output. This encourages unity of direction and action and coordination (Godwin et al., 2017) and Drucker, (1954) stated that this is because organisations operate on first established objectives. Meanwhile, this must not be seen as a conflict to another department or section which has its own specific objectives for specific outcomes.

Hence forth, Henry Fayol establishment was that organisations first have a central objective as the main directive together with departmental objects and goals as well as group aims and objectives, and all needs to be outstanding in order to achieve the ultimate objective of the organisation. Is this how public sector organisations operate and do they achieve good results?

\subsection{Good Governance in the Public Sector}

Almost all the Ghana Shared Goals and Development Agenda (GSGDA) as a strategic policy objectives are in consonance with the Municipal District Assemblies (MDAs) strategic policy objectives and this is to make sure that policies are well implemented for the achievement of good governance for economic growth. During the 20th century, public administration in the sub-Saharan African countries has undergone multiple reforms with significant implications towards education, training, and preparation of individuals to participate in the practice in development management of their countries. Therefore, most recent reforms in good governance in Africa, is a concept that the international donor communities has pursued based on which developmental assistance is given to Africans (European Union [EU], 2006; Organization for Economic Cooperation and Development [OECD], 2007; World Bank, 2008; United Nations [UN], 2009; Doeveren, 2011; Haruna and Kannae, 2013). But does this improve the organisational achievements through the public sector organisational charts/structures? There is a case of Public Utilities Regulatory Commission (PURC) that had increased electricity tariffs by 59.2 percent in December 2015 and by this a disgruntled resident narrated his frustration to citifmonline that he bought GHs50.00 worth of power into his electricity meter, but it got finished in just two days. Low and behold, this resident said when he visited the Electricity Company of Ghana (ECG) office over the matter, he was told by customer service that someone had recharged GHs3,000.00 which got finished within three days, hence he has no cause to complain. This is an example of governance services most Ghanaians receive from the public sector management who are suppose to champion good governance. Has the employee of ECG used proper initiative to answer the complaint? Are do the public authorities' checks on how employees behave with unity of direction or objective if they have one?

The essence of good governance is supposed to propel economic growth and development but base on a critical perspective, South Africa is a middle income country with pockets of first world characteristics, such as infrastructure with some luxurious places of the population. But ironically, the majority of people constituting more than $85 \%$ of the country's population who live in the rural areas are extremely poor and this situation is not likely to change unless principles of management for good governance are practiced at all spheres of government and in all state institutions including its public enterprises and Ghana is not an exception. Matei et al., (2016), noted that good governance as a right, represent new concerns to both national and the European governmental authorities. This concept brings about the introduction of a new managerial way of thinking also in the national or local public administration systems of work. This trend was operationalized theories and practices specific to the New Public Management or Weberianism, supported by international bodies, like the World Bank, International Monetary Fund and OECD.

The term "good governance" has been extensively used within the international community in the last twenty-five years and has achieved the characteristics of a term "container concept", which incorporates a variety of principles in general concepts known as globalisation or global governance. Hence there is no single 
definition for it which is, any attempt to define it would lead to a long discussion of what is governance as well as to a normative search of what is "good" governance. Good governance is a term different to governance which is mainly a political and technocratic term without normative aspirations and suggests that governance should be "good" and not "bad" (Ladi, 2008). In order to make public services effective and transparent, the local public authorities and institutions have the duty to perform their duties towards the achievement of the general interest of the citizens by applying the principles of management such as authority, initiative, and unity of direction for the achievement of good governance. The principles of good governance accepted by most European states defined as good governance standard for public policies are those which focus on outcomes for citizens through transparency in decision-making, risk management assessment, development of the people capacity and capabilities for efficient governance, and accountability. The question then is how can this be achieved through public organisations structure?

Kofi Annan, the former UN Secretary General describes good governance as a force ensuring respect for human rights and the rule of law, and strengthening democracy, and promoting transparency and capacity in public administration at all times (Ladi, 2008). How can this be achieved if public sector organisations do not practice proper Hency Fayols principles of management? Today, the use of the term good governance has been expanded to include more than multiparty elections, a judiciary and a parliament. The areas of interest are "universal protection of human rights meaning non-discriminatory laws; efficiency, impartial and rapid judicial processes; transparent public agencies; accountability for decisions by public officials; devolution of resources and decision-making from the capital to local levels; and meaningful participation by citizens in debating public policies and choices" (Ladi, 2008). This is the challenge of African continent since their practice of democracy for good governance seems to be misdirected since they have poor implementation of organisational charts and structures. Below is a proposed theoretical framework from the above literature reviewed:

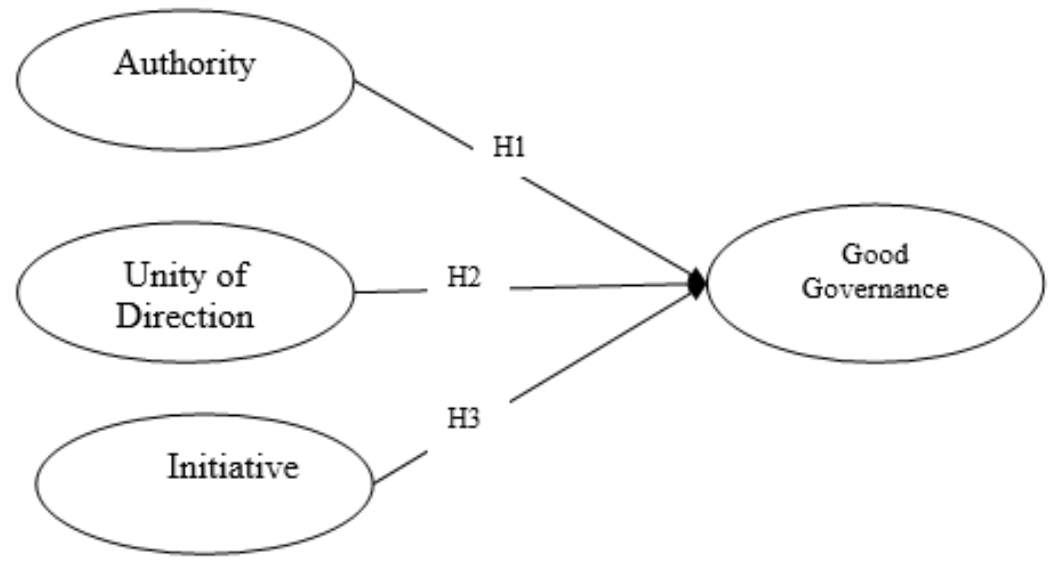

Figure 9.Theoretical Model/Conceptual Framework

Table 1. Codes of the data used and meaning of the corresponding factors/variables

\begin{tabular}{|l|l|}
\hline code & Corresponding factor/Variable \\
\hline gg & Good governance \\
\hline auth & Authority \\
\hline uniodir & Unity of Command \\
\hline Initiatv & Initiative \\
\hline pwill & Government uses Political Will power \\
\hline corruptn & There is corruption in Ghana \\
\hline auth2b & The is Authority is the Public Sector Organisations \\
\hline unityd2e & Job description is given to employees \\
\hline unityde1 & There is teamwork in the Public Sector Organisations \\
\hline initiat & Public Sector workers adds their initiatives in the overall goals and objectives \\
\hline
\end{tabular}

\section{Methodology}

This is a qualitative and quantitative study technique where by both open-ended and closed questions where developed in the instrument designed as the questionnaire together with the assessment of documents on organisational charts/structures. The target population for this research for primary data is the Ghana National Association of Teachers (GNAT) within the Tamale Metropolis. A total of numbers of 68 questionnaires were distributed and only 55 responded. And by this the researcher adopted GPower 3.0.10 and calculated a scientific sample size. GPower provides effect size calculators and a graphic option which supports both a distribution- 
based and a design-based input mode and it contains a calculator that also supports many central and non-central probability distributions. This research uses Mplus v8 to compute the data for analysis of the various relationships that exist between the independent variables (authority, initiative, and unity of direction) and the influences each of these variables have on good governance as achievement for the country. In this case a survey was conducted in a form of simple random sampling method. Below is the GPower calculated data to support the sample size used. The GPower total sample size given is 54 at $95 \%$ margin of error with significance of 0.05 , but 55 responses were collected and used.

$\begin{array}{lll}\text { Exact - Correlations: Difference from constant (one sample case) } \\ \text { Options: } & \text { exact distribution } \\ \text { Analysis: } & \text { A priori: Compute required sample size } \\ \text { Input: } & \text { Tail(s) } & =\text { Two } \\ & \text { Effect size } r & =0.3 \\ & \alpha \text { err prob } & =0.05 \\ & \text { Power (1- } \beta \text { err prob) } & =0.95 \\ & \text { Population correlation } \rho & =0.67 \\ \text { Output: } & \text { Lower critical } \rho & =0.495307 \\ & \text { Upper critical } \rho & =0.797423 \\ & \text { Total sample size } & =54 \\ & \text { Actual power } & =0.950397\end{array}$

Figure 10.GPower Sample Size Calculated

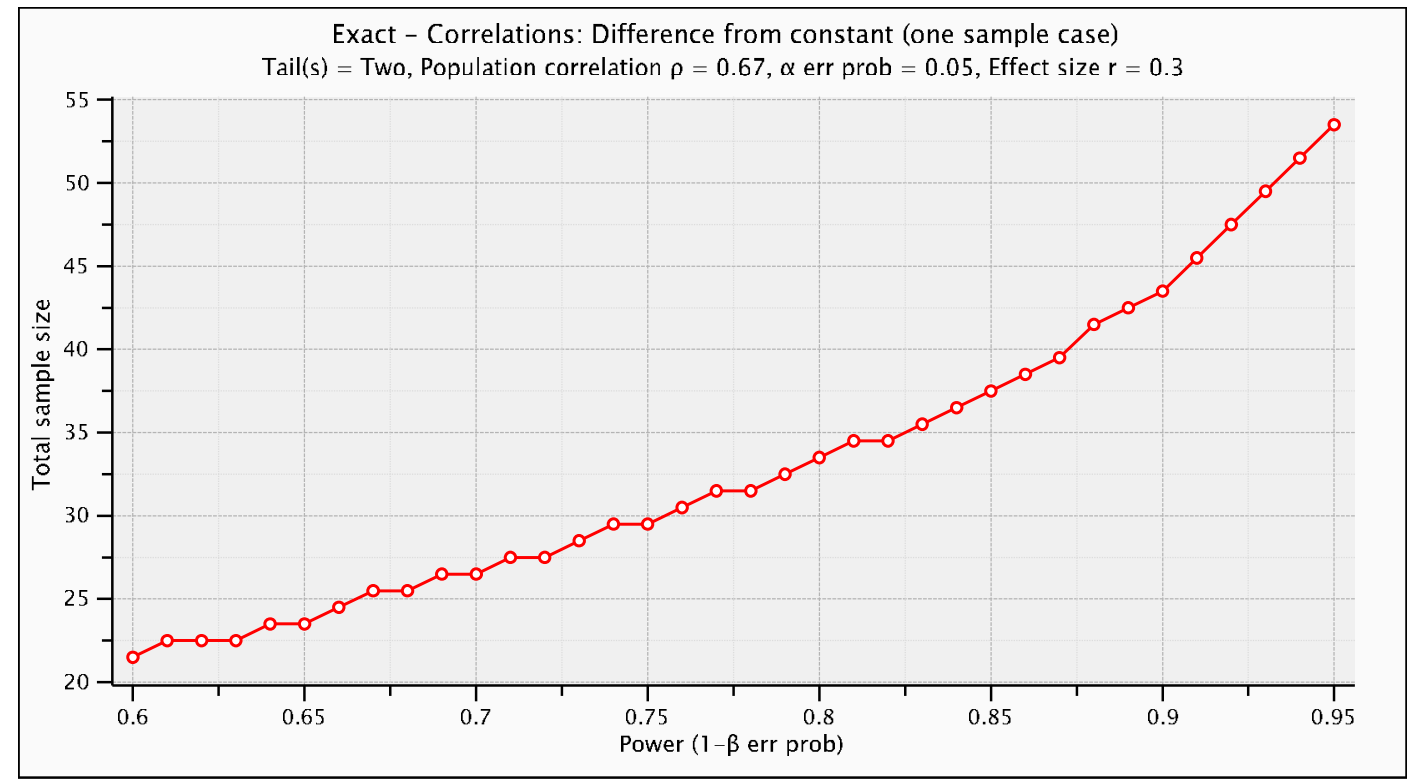

Figure 11.GPower Sample Size Calculated graph

\section{Findings and Discussion}

Confirmatory Factor Analysis (CFA)/SEM (Mplus v8) 


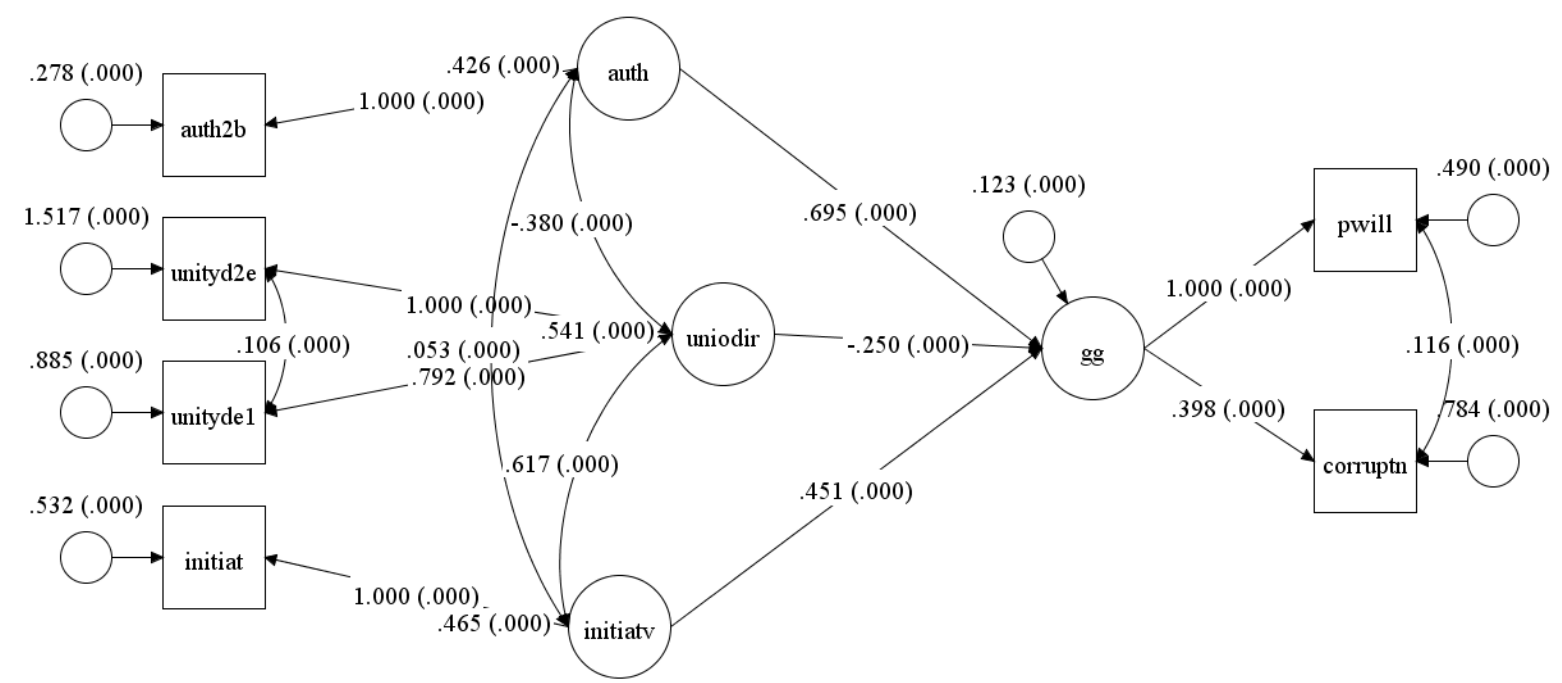

Figure 12. Conceptual Model Results

The above figure 10 shows that path model of auth-gg has positive coefficient of 0.695 which means that they are positively correlated. Also, the path of initiatv-gg has a positive coefficient of 0.451 and that indicates that there is positive relationship, whereas uniodir-gg has a negative coefficient of -0.250 which means that there is negative (or reject hypothesis) relationship.

SAMPLE STATISTICS

Means

\begin{tabular}{llllll} 
PWILL & CORRUPTN & AUTH2B & UNITYD2E & UNITYDE1 & INITIAT \\
\cline { 1 - 1 } & & & &
\end{tabular}

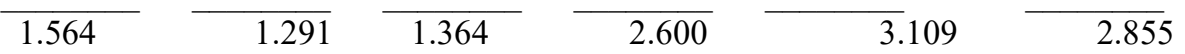

The highest mean is UNITYDE1 which is 3.109 meaning it is the highest frequency in the data run followed by INITIAT which has a mean of 2.855 , and then followed by UNITYD2E which has a mean of 2.600 , and the rest mean score is below 2.000 .

\section{Covariances}

PWILL CORRUPTN AUTH2B UNITYD2E UNITYDE1 INITIAT

PWILL CORRUPTN

AUTH2B

UNITYD2E

UNITYDE1

INITIAT

\begin{tabular}{c}
\hline $\mathbf{0 . 9 7 3}^{*}$ \\
$\mathbf{0 . 3 0 9}^{*}$ \\
$\mathbf{0 . 4 1 3}^{*}$ \\
-0.338 \\
0.084 \\
0.118
\end{tabular}

\subsection{1*}

\subsection{5*}

$-0.411$

0.023

$-0.212$

\subsection{4}

$-0.564$

$-0.167$

0.053
2.058

0.535

0.469

1.224

0.598

0.997

\section{Correlations}

\section{PWILL}

AUTH2B

\begin{tabular}{l}
\hline $\mathbf{1 . 0 0 0}$ \\
$\mathbf{0 . 3 3 7}$ \\
$\mathbf{0 . 4 9 9}$ \\
-0.239 \\
0.077 \\
0.120
\end{tabular}

CORRUPTN

$\mathbf{1 . 0 0 0}$
$\mathbf{0 . 2 3 8}$
-0.309
0.022
-0.229

$-0.229$

\subsection{0}

$-0.468$

$-0.180$

0.063
0.120
UNITYD2E

UNITYDE1

INITIAT

PWILL

AUTH2B

UNITYDE1

INITIAT
1.000

0.337

0.327

1.000

$0.541 \quad 1.000$ 


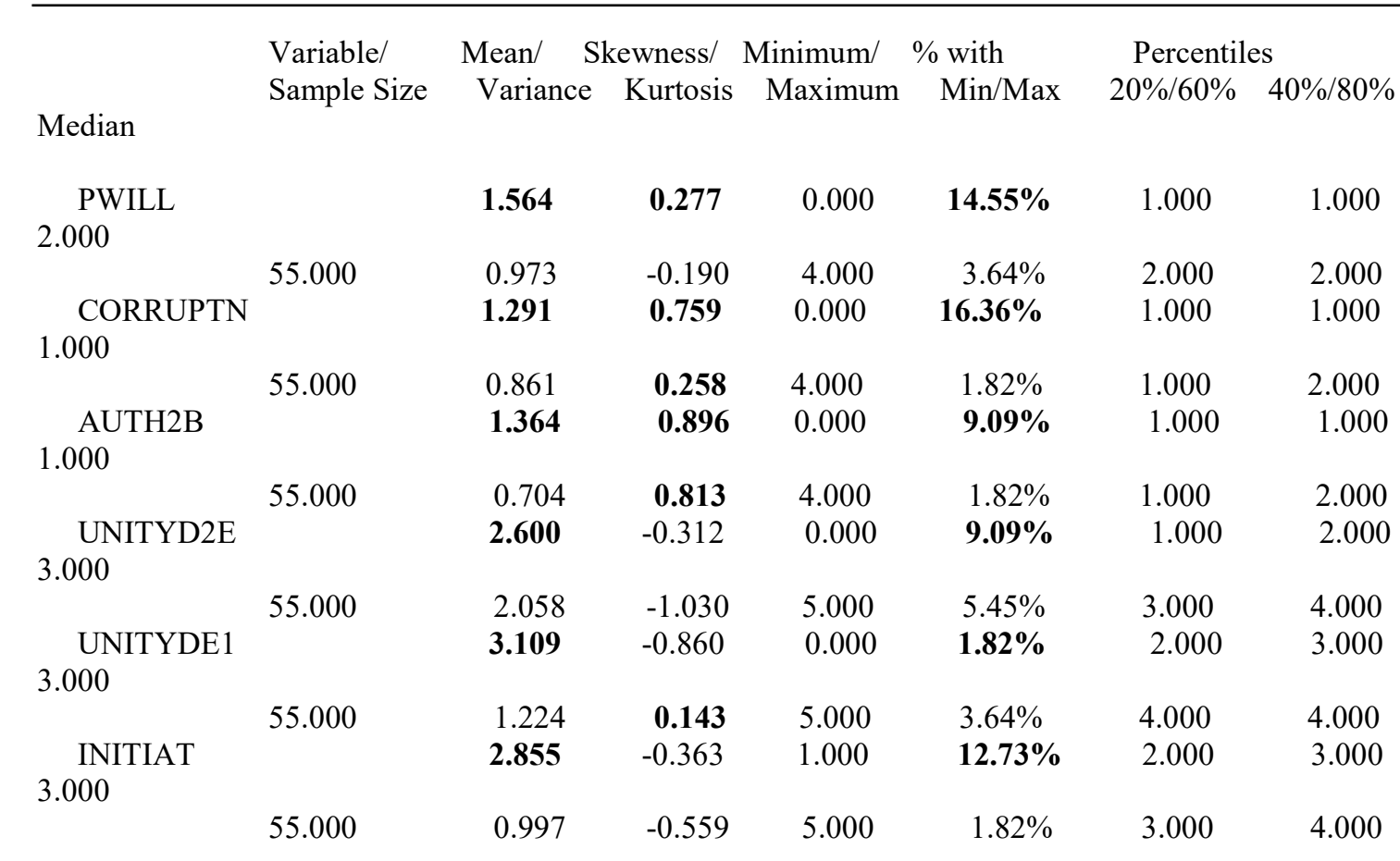

Skewness and Kurtosis are software descriptive statistic functions that are commonly listed values in the output results. Skewness is used to measure distributions called symmetry and its data set is equal to 0 , which then means the distribution is normal. It measures the relative two tail sizes as adopted in this research whereas Kurtosis is also a measure of two tails in combined sizes. Kurtosis normal distribution is equal to 3 and if it is greater than 3 it means that the data set has a heavier tails (more in tails) than normal distribution but if the kurtosis is less than 3 then it means that it has a lighter tails than the normal distribution.

Hence, from the above data results it indicates that no skewness (no zero) but there is lighter kurtosis which are $0.277,0.759,0.258,0.896,0.813$, and 0.143 .

\section{MODEL RESULTS}

\section{Estimate}

GG BY

$$
\text { PWILL }
$$

CORRUPTN $\quad 0.398$

AUTH BY
AUTH2B

1.000

$\begin{array}{ll}\text { UNIODIR BY } & \\ \text { UNITYD2E } & 1.000 \\ \text { UNITYDE1 } & 0.792\end{array}$

INITIATV BY

INITIAT

\section{GG ON \\ AUTH \\ UNIODIR \\ INITIATV}

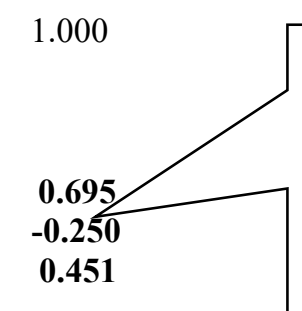

This is where the hypothesis is confirmed or otherwise. It means that only AUTH has 0.695 as the higher coefficient meaning it has positive relationship and influence on GG, whereas INITIATV has a value of 0.451 as a positive relationship and influence on GG. But only UNIODIR has a negative coefficient of -0.250 which means there is no effective correlation between GG and UNIODIR. GG has the $\mathrm{R}^{2}$ of 0.123 . (Also, see figure 10 as above). 
AUTH $\quad-0.380$

$\begin{array}{ll}\text { INITIATV WITH } & \\ \text { AUTH } & 0.053 \\ \text { UNIODIR } & 0.617\end{array}$

PWILL WITH

CORRUPTN $\quad 0.116$

UNITYD2E WITH

UNITYDE1 $\quad 0.106$

$\begin{array}{lc}\text { Intercepts } & \\ \text { PWILL } & 1.564 \\ \text { CORRUPTN } & 1.291 \\ \text { AUTH2B } & 1.364 \\ \text { UNITYD2E } & 2.600 \\ \text { UNITYDE1 } & 3.109 \\ \text { INITIAT } & 2.855\end{array}$

Variances

$\begin{array}{ll}\text { AUTH } & 0.426 \\ \text { UNIODIR } & 0.541 \\ \text { INITIATV } & 0.465\end{array}$

Residual Variances

PWILL

CORRUPTN

AUTH2B

UNITYD2E

UNITYDE1

INITIAT

GG

0.465

0.490

0.278

1.517

0.885

0.532

0.123
These are unstandardized coefficients which indicates the $\mathrm{Z}$ statistic, that is, values that exceed positive $(+1.96)$ or is below negative $(-1.96)$ are those considered significant below a $p$ value $=0.05$. Therefore, this results indicates that only the GG on UNIODIR is $(-0.265)$ that is below -1.96 , as well as it shows correlation between the latent factors UNIODIR WITH AUTH $(-0.792)$ that is below -1.96, and including the positive intercepts which are UNITYD2E, UNITYDE1, and INITIAT with values $2.600,3.109$, and 2.855 respectively, all are greater than positive $(+1.96)$ at $p$ value $=0.05$. The estimates are also listed as above.

In this case it means that only these factors considered here are those that have appreciable factor loadings as statistically significant according to the principle of rules specified and the rest has insignificant loadings.

In this variance and residual variance simply refers to $\mathrm{R}^{2}$ are well presented in figure 10 above where the analysis is defined for GG, UNIODIR, UNITIATV, and AUTH. Following the standardized coefficient of AUTH, UNIODIR, INITIATV, and GG, indicates that UNIODIR is 0.541 which is higher than the other factors followed by UNITIATV which is 0.465 , and then AUTH which is 0.426 , whereas GG has the lowest residual coefficient of 0.123 as the $\mathrm{R}^{2}$. These means that only UNIODIR explains the shared variances better than the rest of the latent factors. This is because it is larger than the rest of the variable coefficients.

STANDARDIZED MODEL RESULTS

StdYX StdY Std

Estimate Estimate Estimate

GG BY

PWILL

0.705

0.705

0.695

CORRUPTN

0.298

0.298

0.277

AUTH BY

AUTH2B

0.778

0.778

0.653

UNIODIR BY

UNITYD2E

UNITYDE1

0.513

0.513

0.735

0.526

0.526

0.582 


$\begin{array}{lccc}\text { INITIATV BY } & & & \\ \text { INITIAT } & 0.683 & 0.683 & 0.682 \\ \text { GG ON } & & & \\ \text { AUTH } & 0.653 & 0.653 & 0.653 \\ \text { UNIODIR } & -0.265 & -0.265 & -0.265 \\ \text { INITIATV } & 0.442 & 0.442 & 0.442 \\ \text { UNIODIR WITH } & & & \\ \text { AUTH } & -0.792 & -0.792 & -0.792 \\ \text { INITIATV WITH } & & & \\ \text { AUTH } & 0.119 & 0.119 & 0.119 \\ \text { UNIODIR } & 1.231 & 1.231 & 1.231 \\ \text { PWILL WITH } & & & \\ \text { CORRUPTN } & 0.188 & 0.188 & 0.116 \\ & & & \\ \text { UNITYD2E WITH } & & & \\ \text { UNITYDE1 } & 0.091 & 0.091 & 0.106 \\ \text { Intercepts } & & & \\ \text { PWILL } & 1.585 & 1.585 & 1.564 \\ \text { CORRUPTN } & 1.391 & 1.391 & 1.291 \\ \text { AUTH2B } & 1.625 & 1.625 & 1.364 \\ \text { UNITYD2E } & 1.812 & 1.812 & 2.600 \\ \text { UNITYDE1 } & 2.810 & 2.810 & 3.109 \\ \text { INITIAT } & 2.859 & 2.859 & 2.855 \\ \text { Variances } & & & \\ \text { AUTH } & & & \\ \text { UNIODIR } & 1.000 & 1.000 & 1.000 \\ \text { INITIATV } & 1.000 & 1.000 & 1.000 \\ \text { Residual Variances } & & & \\ \text { PWILL } & \mathbf{0 . 5 0 3} & \mathbf{0 . 5 0 3} & \mathbf{0 . 4 9 0} \\ \text { CORRUPTN } & \mathbf{0 . 9 1 1} & \mathbf{0 . 9 1 1} & \mathbf{0 . 7 8 4} \\ \text { AUTH2B } & \mathbf{0 . 3 9 5} & \mathbf{0 . 3 9 5} & \mathbf{0 . 2 7 8} \\ \text { UNITYD2E } & \mathbf{0 . 7 3 7} & \mathbf{0 . 7 3 7} & \mathbf{1 . 5 1 7} \\ \text { UNITYDE1 } & \mathbf{0 . 7 2 3} & \mathbf{0 . 7 2 3} & \mathbf{0 . 8 8 5} \\ \text { INITIAT } & \mathbf{0 . 5 3 4} & \mathbf{0 . 5 3 4} & \mathbf{0 . 5 3 2} \\ \text { GG } & \mathbf{0 . 2 5 4} & \mathbf{0 . 2 5 4} & \mathbf{0 . 2 5 4}\end{array}$

\section{Conclusion}

This research has revealed that there are unprofessional and substandard forms of organisational charts or structures that most public sector organisations created. Their structures dissipate the flow of authority likewise its unity of direction and the lacks the concept of employees' initiative. Clearly, from the sample organisational charts and structures in the above have showed that public sector organisational charts cannot be the same as compared with the corporate sector organisational charts in Ghana. From the Public Services Commission (PSC) organisational chart at the top there is the commission, internal auditor, the secretary, secretary's secretariat and public relations officer. This is the type that can be classified as a dissipated chart which is truncated and suppresses the flow of authority and unity of direction. Besides, the commission's chart is too vague, the actual title is important, the internal auditor and the secretary are they superior to the line managers with those titles Directors beneath? It is a misfit organisational chart where authority, unity of direction and initiative from employees may not be successful. Such type of structures breeds the challenges that deter the chances of achieving good governance. Board of Directors or The Governing Council or The Commission are not part of the day to day running of the organisational business, hence, should not be part of the organisational chart. It can be specified in the policy document that establishes the organisation with their function and rules and regulations. 
Again, why is the Administration of staff and all that under the Finance and Audit? This is not best practice it should be under Human Resource Management.

Also, the Local Government Organisational chart takes the same form just as the Public Services Commission (PSC) where at the top they have the local government council, head of service, and chief director. Under the head of service, you have internal auditor, legal affairs and public affairs. Again, these are the type of charts in dissipated nature and can affect authority in one way or the other in addition with unity of direction and employees initiative, where wrongs of the top executives can be concealed, which is bad practice. Why will there be the council at the top of the organisation structure? Is the council part of the day to day running of the organisation? This study has revealed that the way and manner public sectors in Ghana design their organisational charts are misfit to propagate any serious development and advancement towards good governance. So it means that in the local government chart, the internal auditor, legal affairs, and public affairs has no connection, so to speak with the line managers or departments beneath? Another interesting revelation from this study is that the chart has Human Resource Management Directorate, and also Human Resource Development Directorate. Under these two departments, HR planning, recruitment and selection, salary administration, are separate to Training, career development, and performance management and all these are units under the two departments. These are vague and truncated charts not fit for purpose. There is policy planning, budgeting and $M \& E$ directorate in line with other departments and so what is the function of the council, head of service, and chief director? May be signing cheques and approving bills? Clearly the organisational chart is not fit for purpose to drive good governance simply because it means that the top executives can have regular meetings with the internal auditor and the legal officer, and the public relations officer without the line managers. This would be unprofessional and cannot achieve good governance.

In contrast to the above conclusions it is clear that when you consider the 2015 Grand County Organisational Chart, it reveals that they have Citizens at the top of the whole organisation which clearly shows all inclusiveness. Then under it they have County Council and other functions are specified beneath it and then it shows elected officials at both sides through which authority follows downwards including from the council downwards. In this case, there is definitely flow of authority, unity of direction, and use of employees' initiative. This chart is what we call best practice of organisational chart towards achieving good governance.

Final conclusion from the primary data tested on the model for the establishment of the hypothesis, clearly shows as below:

Table 2. Model Test Results

\begin{tabular}{|l|l|}
\hline Hypothesis & Results \\
\hline H1: Authority is positively significant to good governance. & Positive (accepted) \\
\hline H2: Initiative significantly correlate to good governance. & Positive (accepted) \\
\hline H3: Unity of Direction is positively significant to good governance. & Negative (Rejected) \\
\hline
\end{tabular}

The above table 2 implies that to some extend authority and initiative has positive relationship towards achieving good governance through Ghana's public sector organisations whereas unity of direction is seem less successful. Hence, there is the need to find the root causes. Even though, initiative has positive relationship scientifically it has very low coefficient compared to authority. In public sector organisational chart, it must be all inclusive to serve meaning there should not be a boss, or bosses in the public sector organisation but rather servants. This is how humble each public sector office must portray unlike the above type of authoritative charts in the Local Government Service and Public Commission Services. That is, been servants will allow for initiative to be robust within the public sector organisations. Also, it is Public Organisations and not public companies. Besides, you cannot have directorates in the public sector offices when there is constitution directing everything already. The public sectors of Ghana need to revisit a lot of its organisational charts and structures to make them fit for purpose towards achieving good governance. Hence forth, below is suggested dummy for a unique public sector organisation chart. The chart below can be edited accordingly from the National Level to Regional Level and then to Metropolitan Level and District Level in accordance. This type of public sector charts will help bring strong institutional deliverables in the public sector to enhance good governance. 


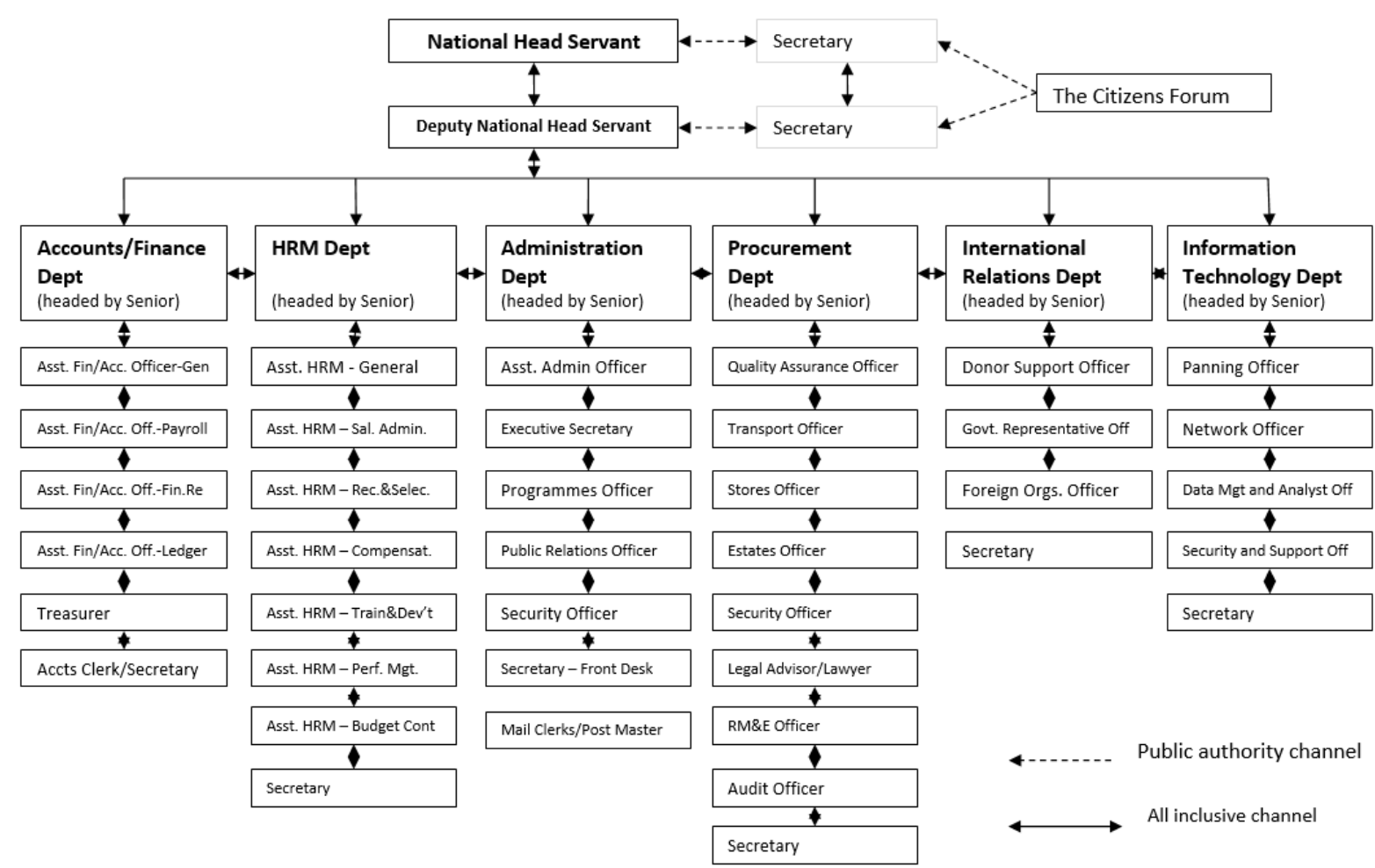

Figure 13.National Level Organisational Chart (Public Office Positions) - All inclusive Charts

\section{Recommendation}

The research proposed that the title of the public sector workers must be change to reflect humbleness of their titled positions to public servants or public office holders. The positions should define their service to the people. Public sector organisations are controlled not just by rules and regulations but with laws and constitution, hence, its positions cannot be competing with those in the corporate and private sectors, they are to serve the nation. Also, public servants don't direct but rather facilitate the work of the public sector. The directives in the public sector are the laws and constitution that establishes it; the servants only comply with and apply those rules and regulations. Further scientific research can be conducted on the model in one particular public organisation to ascertain its correlations and relationships with these variables (authority, unity of direction, and initiative) and also with a larger sample size.

\section{Reference}

Akrani, G., (2010), Organisation - Organisation Structure - Organisational Chart, Kalyan City Life.

Asian Development Bank (2005), Country Governance Assessment - Philippines. http://hdl.handle.net/11540/6353.

Aucoin P., (2012), New Political Governance In Westminster Systems: Impartial Public Administration And Management Performance At Risk, Governance: An International Journal of Policy, Administration, and Institutions, Wiley Periodicals, Inc., Vol. 25, No. 2, pp. 177-199

Aucoin, P. (1990), Administrative Reform in Public Management: Paradigms, Principles, Paradoxes and Pendulums. Governance: Vol. 3, No. 2, pp 115-137.

Aucoin, P., and Heintzman, R., (2000), The Dialectics of Accountability for Performance in Public Management Reform, International Review of Administrative Sciences, Vol. 66, No.1, pp 45-55.

Christensen, T., Laegreid, P., Roness, P.G., and Rovik, K.A., (2007), Organisation Theory and the Public Sector, Instrument, Culture, and Myth, Routledge, United Kingdom: Abingdon

Daniel A. Wren, Arthur G. Bedeian, John D. Breeze, (2002),"The foundations of Henri Fayol's administrative theory", Management Decision, Vol. $40 \quad$ Iss $9 \quad$ pp. $906 \quad-\quad 918$ http://dx.doi.org/10.1108/00251740210441108

Davis, S. M., and Lawrence, P.R., (1978), “Problems of Matrix Organizations.” Harvard Business Review, Vol. 56, No. 3, pp. 131-42.

Davis, S.M., and Lawrence, P.R., (1978), Organisational Structure, Problems of Matrix Organisations, Harvard Business Review

Doeveren, V., (2011), Rethinking governance identifying common principles, Public Integrity, Vol. 13, No. 4, pp. 301-318 
Drucker, P.F., (1954), The practice of management, Harper Business: New York.

European Union. (2006). The European consensus on development. Official Journal of the European Union, C46.

Feldman M. S., and Khademian A. M., (2001), Principles for Public Management Practice: From Dichotomies to Interdependence, Governance: An International Journal of Policy and Administration, Vol. 14, No. 3, pp. 339-361

Gilman, S.C., (2005), "Ethics codes and codes of conduct as tools for promoting an ethical and professional public service: Comparative successes and lessons." Washington DC: USA.

Godwin, A., Handsome, O.E., Ayomide, W.A., Enobong, A.E., and Johnson, F.O., (2017), Application of the Henry Fayol Principles of Management in Startup Organisations, IOSR Journal of Business and Management, Vol. 19, No. 10, pp. 78-85

Haruna, P.F., and Kannae, L.A., (2013), Connecting Good Governance Principles to the Public Affairs Curriculum: The Case of Ghana Institute of Management and Public Administration, Journal of Public Affairs Education, Vol. 19, No. 3, pp. 493-514

Heywood, A., (1997) Politics. Macmillan, London.

Ladi S., (2008), Good Governance And Public Administration Reform In The Black Sea Economic Cooperation (BSEC) Member States, International Centre for Black Sea Studies, Multimedia Ltd: Athens (Greece)

Magjuka, R. F., (1991; 1992). Survey: Self-managed teams achieve continuous improvement best. National Productivity Review (Spring), 203-211.

Matei L., Matei A., and Lazar C. G., (2016), Public service performance and good administration. Socioeconomic empirical evaluations, Procedia Economics and Finance vol. 39 pp. 335 - 338, doi: $10.1016 / \mathrm{S} 2212-5671(16) 30332-\mathrm{X}$

New York Times report, (2009), Obama Delivers Call for Change to a Rapt Africa, https://www.nytimes.com/2009/07/12/world/africa/12prexy.html accessed 12th December, 2018

Okpara, F. C., (2016), Henry Fayol's 14 Principle of Management and it's applications to a Bank.

Organization for Economic Cooperation and Development (OECD). (2007). Glossary of statistical terms: Good governance. Retrieved from http://stats.oecd.org/glossary/detail accessed 06/01/2016

Skipton, M. D. 'Management and the Organisation', Management Research News, vol. 5, no. 3, 1983, pp. 9-15.

United Nations Development Program (1997), Governance \& Sustainable Human Development, A UNDP Policy Document

United Nations. (2009). What is good governance? Retrieved from http://www.unescap.org/pdd/prs/ProjectActivities/Ongoing/gg/governance/asp accessed $06 / 01 / 2016$

World Bank, (2008), Governance matters VII: Aggregate and individual governance indicators, 1996- 2007, World Bank Policy Research, Working Paper 4654. 